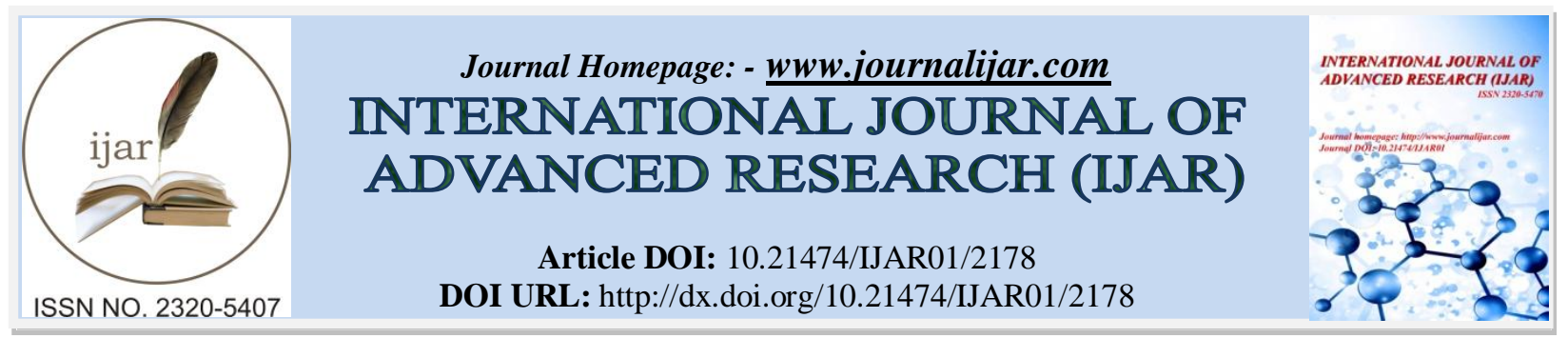

RESEARCH ARTICLE

\title{
CYTOGENETIC STUDIES ON A MULBERRY (MORUS SP.) HYBRID OF A CROSS BETWEEN DIPLOID AND TRIPLOID PARENTS.
}

*R. Ravi Kumara and Basavaiah.

Mulberry Breeding and Genetics Laboratory, Department Of Studies in Sericulture Science, University Of Mysore, Manasagangotri, Mysuru -570 006. Karnataka, India .

\section{Manuscript Info}

Manuscript History

Received: 26 September 2016

Final Accepted: 29 October 2016

Published: November 2016

\begin{abstract}
Mulberry exhibits wide range of plasticity and taxonomical confusion due to cross pollination and heterozygous nature of the plant. Ploidy level of the plant varies and majority of the plants are diploid in nature and some exhibited triploid and polyploidy nature. Three genotypes were selected viz., Bird's foot, Suvarna-1 and F1 hybrid of Bird's foot and suvarna-1. Cytomorphological characters indicated that Bird's foot is diploid with $2 \mathrm{n}=28$ and suvarna- $12 \mathrm{n}=3 \mathrm{x}=42$ whereas F1 hybrid showed aneuploidy (trisomic)character and is different from both the parents and recorded $2 n=2 x+1=29$.
\end{abstract}

Copy Right, IJAR, 2016,. All rights reserved.

\section{Introduction:-}

Mulberry includes a large number of species of the genus Morus L. which are having great economic importance. Many of these species and their hybrids are being cultivated in many parts of the world as food plants of the silkworm, Bombyx mori L. to practice sericulture. As the leaf of mulberry is the sole food of this domesticated silkworm.

The suitability of mulberry variety for commercial cultivation has to be considered from two aspects. First, agrobiological characters like good rooting, fast growth, adaptability to environmental and soil conditions and resistance to diseases and pests. Secondly, superior leaf quality to fulfill the nutritional requirements of young age and late age silkworm.

Genetic improvement of mulberry for its foliage characters both in qualitative as well as quantitative aspects is the long-term goal for mulberry breeders. The genetic improvement of mulberry depends on the availability of genetic variability in germplasm. Selection of suitable genotypes from gene pool requires a thorough knowledge on foliage characters for utilizing them in hybridization programmes (Dandin et al.,2003).

\section{Materials and methods:- \\ Hybridization:-}

For hybridization two genotypes, Bird's foot and Suvarna-1 which are used as female and male parents respectively were collected from KSSRDI, Bangalore. The Hybridization experiment was conducted in the village B.V. Halli, ChannapatnaTaluk, Ramanagaram District.

Corresponding Author:- R. Ravi kumara.

Address:- Mulberry Breeding and Genetics Laboratory, Department Of Studies in Sericulture Science, 
The genotype Bird's foot is a low yielding variety with distinct leaf lobation. Its leaves are deeply lobed, rough surface, coriaceous, caudate apex, serrate margin (Fig.1-2). Suvarna-1 is a fast growing high yielding genotypes with unlobed, deep green, succulent leaves and good root proliferation (Fig. 3-4).

The parents were middle pruned on August (Rainy season) 2013 to obtain flowers. After flowering the female inflorescences were covered with butter paper bag to avoid wind pollination. The male inflorescences were collected from Suvarna-1 and pollination was conducted with the hand by putting the male inflorescence on female inflorescence. After crossing the female inflorescences were immediately bagged again. After one month the ripened fruits were harvested, seeds were extracted from the fruits, dried in shade and stored in paper covers until sowing.

After a month, the seeds were sown in a seed pots and maintained by regular sprinkling of water. The seedling developed good root and shoot system in five months. A total of eight seedlings were selected and were transferred to the field after five month in $90 \mathrm{~cm} \mathrm{X} 90 \mathrm{~cm}$ spacing. They were studied for their growth, leaf yield per plant and leaf nature (unlobed, broad, smooth surface, dark green color) and best performing one was identified and multiplied for further studies.

\section{Cytological studies:-}

Mitotic and meiotic studies were made in the parents and also in the hybrid. The shoot tips and male flower buds were sampled from these plants. The cuttings are planted in earthen pots to get the root tips.

Meiotic studies:- Meiosis during microsporogenesis was studied in young anthersofSuvarna-1 by employing standard technique of fixation and smear preparation as follows. The young catkins of appropriate stage of development were fixed in Carney's-II solution (6:3:2 Absolute alcohol:chloroform:propionic acid)between 8am and 10am on sunny day and kept for 12-14hrs. Fixed materials were preserved in $70 \%$ alcohol and stored in refrigerator. At the time of study, anthers were dissected out from appropriate buds and smear of pollen mother cells was made on a clean slide in $2 \%$ propiono-carmine and a cover slip was placed on the smear. The slide was heated gently over a spirit lamp to intensify the stain. Gentle pressure was applied over cover slip to get uniform spreading of chromosomes by placing the slide between the folders of blotting paper. The slides were made semi permanent by sealing the cover glass with molten paraffin wax.

\section{Pollen fertility and pollen size:-}

Fresh and mature anthers ready for dehiscence were used to determine pollen fertility and pollen size. The pollen were dusted on a clean slide and stained with $1 \%$ aceto-carmine. The pollen which were morphologically normal and taken good staining were scored as fertile, while those which were shrunken and unstained were scored as sterile. The pollen fertility was expressed in percentage. Pollen size was measured using micrometers.

Mitotic studies:- Mitotic studies were made in root tips by following the standard technique of pretreatment, fixation and squash preparation as detailed below:

\section{Pre-treatment and fixation:-}

Actively growing roots were collected and root tips were excised at around $11 \mathrm{am}$. The root tips were pre-treated with $0.5 \%$ Colchicines for $4 \mathrm{~h}$, washed with water and then fixed in carneys-I solution i.e.(acetic acid and absolute alcohol) for 18-24 hours at room temperature.

\section{Maceration, squash preparation and photomicrography:-}

The fixed root tips were washed in distilled water and then hydrolyzed in 1N HCL for 6-7 minutes. The hydrolyzed material was washed with distilled water and placed in Schiff's reagent (Feulgen stain) for $1 \mathrm{~h}$. The stained root tips were washed and placed in dilute solution of cellulose for 10-12 h. The softened stained root tips were squashed in $45 \%$ acetic acid or $0.5 \%$ aceto-orcein. The smear was covered with cover slip. Then slide was kept between folds of blotting paper and gently pressure was applied with flat bottom of a pencil. The cover slip edges were sealed with paraffin wax. These temporary slides were observed under leitz microscope. The selected stages were photographed. Studies on morphology, anatomy, reproductive, growth parameters and biochemical feature sare studied by following the standard procedures described in the mulberry germplasm catalogue of CSGRC, Hosur (Thangaveluetal.,,1997) 


\section{Results:- \\ Morphological, anatomical and biochemical studies:-}

The data on morphological features of the parents and the F1 hybrid (Fig.5-6) is presented in Table-1. In morphological features the F1 hybrid showed intermediate nature between female and male parents. The branching nature, phyllotaxy, stipule nature, leaf base and leaf shape are all similar in the hybrid as well as its parents. The hybrid resembles Bird's foot, its female parent in leaf color, sex expression and rarely occurring lobed leaves. It resembles male parent Suvarna-1 in leaf color, lobation, shape, surface, texture, apex etc. Further, it is intermediate between male and female parents in majority of the characters especially in leaf length, width, leaf size and petiole size. The F1 hybrid and other F1 progenies showed various types of lobed leaves in the initial development of seedlings (Figs.7 -10).

The F1 hybrid is characterized for its reproductive features in comparison with its parent and the data are presented in Table-2. Unlike, its parents it showed stable condition in sex expression with only female inflorescence in all the seasons. On thecontrary its female parent Bird's foot exhibit complete female flowers only during rainy season. Length of its inflorescence was almost equal to that of its parents. The number of flowers was found reduced when compared to its female parent. It resembles its male parent with its increased peduncle length. The style length of hybrid also found increased over its female parent. The fruit size of the hybrid is intermediate between the male and female parent.

The growth parameters of the hybrid are studied with comparison with its parent and data are recorded in Table-3. In all the growth parameters the hybrid has improvement over its female parent. But, it is found inferior to its male parent in almost all growth parameters.

The hybrid also showed good rooting percentage with high percentage of survival and growth characteristics of the saplings (Table-4).

Anatomical studies of the leaf of the hybrid also showed distinctiveness of hybrid over its parents. Its stomata size is significantly higher than its diploid parent but lower than its triploid parent and also stomata frequency is remarkably higher in F1 hybrid. Though, the leaf size of the hybrid is intermediate between the diploid and triploid parents its leaf thickness is lower than both of its parents (Table-5).

To characterize the trisomic hybrid of cross between diploid and a triploid its biochemical characters are also compared with that of its parents. The data on various biochemical parameters studied is presented in Table- 6 . There was no significant difference between the parents and hybrid in leaf protein content. Similarly, the hybrid doesn't differ from its parents in carbohydrate content of its course leaves. But, there were highly significant differences in tender and medium leaves. The hybrid showed lesser chlorophyll content over its parents and hence, its leaf is light green in color. Moisture content and moisture retention capacity are also found good in the F1 hybrid of the present study.

\section{Cytological studies:-}

Mitotic studies in mulberry genotype Bird's foot:-

Mitotic studies in mulberry genotype Bird's foot revealed that there is sticky nature of chromosomes at their ends (Fig.11). As a result, there was no proper spreading of chromosomes at metaphase. The study with sufficient number of cells of root tips indicated that there are 28 somatic chromosomes (Fig. 12\& 13). All the somatic cells studied showed almost normal mitosis. Rarely chromatin bridges are recorded during anaphase separation of chromosomes (Fig. 14).

\section{Meiotic studies in mulberry genotype Suvarna-1:-}

Mitotic studies with the shoot tip cells established the chromosome number of this genotype as $2 n=3 x=42$ (Fig. 15). Meiosis during microsporogenesis was studied in Suvarna-1 and it was found irregular. All the pollen mother cells of an anther showed highly synchronized meiotic divisions. During prophase-I PMC's showed early condensation of some bivalents (Fig. 16). At the end of diakinesis there were 14 highly condensed chromosome groups. At the beginning of metaphase-I 14 trivalents were recorded in majority of PMC's. Some PMC's also showed varied number of trivalents along with few bivalents and univalent. The trivalents aligned normally on the equatorial plate (Fig. 17). Anaphase-I separation was found irregular (Fig. 18). The number of chromosomes moving to opposite poles was unequal in majority of the PMC's studied. The frequency of laggards was also high. 
Meiosis-II was also highly irregular in Suvarna-1. At metaphase-II many scattered chromosomes in the cytoplasm are recorded. There was unequal anaphase-II separation and lagging of 6-10 chromosomes. Very few tetrads showed four spore cells of uniform size and majority of them were with unequal sized spores (Fig. 19). Apart from tetrads, dyads, triads, pentads (Fig.19) with wide range of cell size were also frequently seen. Pollen grains were highly variable in size (Fig. 20). The pollen viability was around 50 per cent indicating high level of sterility in this triploid genotype.

\section{Mitotic studies in F1 hybrid of mulberry:-}

Mitotic studies in the F1 hybrid of Bird's foot and Suvarna-1 also indicated some degree of stickiness at the ends of chromosomes. As a result there was no proper spreading of chromosomes at metaphase. The mitotic anaphase separation of chromosomes was found normal (Fig.21\& 22). The study with sufficient number of cells of root tips indicated that there are 28 somatic chromosomes (Fig. 23). All the somatic cells studied showed almost normal mitosis.

\section{Discussion:-}

Cytogenetic information in mulberry is scanty. Even the reports establishing the chromosome number of mulberry genotypes are very few. Also the chromosomes are various germplasm accessions is not determined and documented in the catalogue of mulberry germplasm (Thangaveluet al.,1997). In the present breeding work, two mulberry genotypes- Bird's foot and Suvarna-1 are used as parents. Thisstudy is the first report recording the chromosome number in the genotype Bird's foot which has $2 \mathrm{n}=28$. Further, Suvarna-1 which developed at KSSRDI, Bangalore by crossing M-5 (4x) as female andViswa(2x) as maleparent is reported as triploid $(2 \mathrm{n}=3 \mathrm{x}=42)$ (Eswar Rao et al.,2014).

Various workers have studied inheritance of leaf lobation patterns in mulberry (Gray et al.,1987). The hybrid of lobed female and unlobed male is characterized by completely unlobed leaves like its triploid male parent suggesting that the dominance of unlobed condition may be due to triploid genome over diploid genome. Occasionally occurring lobed leaves in the hybrid also indicate the unstable nature of leaf lobation in the hybrid. In this study emphasis is laid to understand the chromosome number of hybrid obtained from a cross between the diploid, Bird's foot and triploid, Suvarna-1. In various crop plants aneuploids have been generated by crossing diploid with triploid. Many studies was established the importance of aneuploids in cytogenetic research.

The mitotic studies of Bird's foot clearly established that, chromosome of this genotypes is $2 n=28$ and it also showed normal mitosis. Suvarna-1 is a male parent of the present hybrid and is a triploid with chromosome number $2 n=3 x=42$. The present work also confirms its chromosome number of Suvarna- 1 which is characterized by having irregular meiosis. Irregular meiosis leads to reduced fertility and pollen grains of highly variable size. The variable sized pollen grains are resulting from variable chromosome number separated during anaphase movement.

The F1 hybrid of the present study is important from two aspects. Firstly, with regard to the chromosome number and secondly, with regard to inheritance of lobation of leaf. The mitotic studies of the hybrid established its chromosome number as $2 n=2 x+1=29$. Hence, it is a trisomic. Since, various kinds of trisomics carry an extra chromosome, the genetic ratios for the genes which are located on that chromosome are modified in the segregating progenies. In fact, trisomic segregations have been studied extensively in all the genetically well investigated plant species, such as maize, tomato, barly, datura, wheat, etc. primary trisomics provide an excellent cytogenetic tool for testing the independence of linkage groups and for assigning linkage groups to particular chromosomes (Khush, 1973). In this context, the trisomic of the present study is having a lot of importance in mulberry breeding and cytogenetics. However, for further exploitation of this hybrid as trisomic requires the confirmation of its chromosome number with good cytological preparations. The extra chromosome of the compliment can be identified by employing chromosome banding techniques.

The characterization of hybrid indicated that it is having a good combination of leaf yield and quality parameters. Though, the hybrid is showing unlobed leaves like its male parent its morphological, reproductive and growth parameters indicate its intermediate nature between the parents. The anatomical and biochemical parameters of the hybrid also establish its intermediate nature between Bird's foot and Suvarna-1.

The hybrid though not important as improved variety for commercial exploitation, it may serve as breeding stock with a good combination of leaf yield and leaf quality parameters. 


\section{Summery \&Conclusion:-}

The present study established the chromosome number of the hybrid as $2 n=2 x+1=29$, a trisomic. Further, the chromosome numbers of Bird's foot and Suvarna-1 also confirmed through this study. The trisomic identified in this study has lot of importance in mulberry cytogenetics and breeding. However, further confirmation of chromosome number of this hybrid beyond doubt is also required.

In this preliminary characterization, the hybrid appears to be inferior to its male parent Suvarna-1, an improved genotype in relation to leaf yield and quality determining parameters. But, it is having a good combination of characters in relation to leaf yield and leaf quality. The hybrid, though not important as an improved variety for commercial exploitation, it serves as a breeding stock with good combination of leaf yield and leaf quality characters.

Table-1: Data on morphological features of the parents and the F1 hybrid

\begin{tabular}{|l|l|l|l|l|}
\hline $\begin{array}{l}\text { Sl. } \\
\text { No. }\end{array}$ & Morphological features & $\begin{array}{l}\text { Female parent } \\
\text { (Bird's foot) } \\
\text { Diploid }\end{array}$ & $\begin{array}{l}\text { Male parent } \\
\text { (Suvarna-1) } \\
\text { Triploid }\end{array}$ & $\begin{array}{l}\text { F-1 hybrid } \\
\text { (Trisomic) }\end{array}$ \\
\hline 01 & Branching nature & Semi erect & Simple, Erect & Erect \\
\hline 02 & Straightness & Straight & Open spreading & Straight \\
\hline 03 & Color of young shoot & Purple green & Grayish green & Green \\
\hline 04 & Color of mature shoot & Greenish brown & Greenish brown & Grey green \\
\hline 05 & Phyllotaxy & $1 / 2$ & $1 / 2$ & $1 / 2$ \\
\hline 06 & Stipule nature & Free lateral & Free lateral & Free lateral \\
\hline 07 & Stipule duration & Caducous & Caducous & Caducous \\
\hline 08 & Lenticels density(NO./cm2) & 8 & 6 & 6 \\
\hline 09 & Lobation type & Deep lobed & Unlobed & Unlobed \\
\hline 10 & lobation number & 10 to 14 & - & - \\
\hline 11 & Leaf color & Green & Dark green & Dark green \\
\hline 12 & Leaf nature & Homophyllous & Homophyllous & Homophyllous \\
\hline 13 & Leaf surface & Rough & Succulent & Smooth \\
\hline 14 & Leaf texture & Coriaceous & Chartaceous & Chartaceous \\
\hline 15 & Leaf apex & Caudate & Acuminate & Acuminate \\
\hline 16 & Leaf margin & Serrate & Serrate & Dentate \\
\hline 17 & Leaf base & Cordate & Cordate & Cordate \\
\hline 18 & Leaf shape & Ovate & Ovate & Ovate \\
\hline 19 & Leaf length(cm) & 25.62 & 21.61 & 18.86 \\
\hline 20 & Leaf width(cm) & 19.06 & 15.71 & 13.1 \\
\hline 21 & Petiole width & 0.43 & 0.51 & 0.49 \\
\hline 22 & Petiole length(cm) & 4.7 & 5.5 & 3.5 \\
\hline
\end{tabular}


Table-2:- Data on reproductive characters of the parents and the F1 hybrid

\begin{tabular}{|c|c|c|c|c|c|}
\hline \multirow{2}{*}{\begin{tabular}{|l} 
SI. \\
No.
\end{tabular}} & \multicolumn{2}{|l|}{ Reproductive characters } & \multirow{2}{*}{$\begin{array}{l}\text { Female parent } \\
\text { (Bird's foot) } \\
\text { Diploid } \\
\text { MFBI }\end{array}$} & \multirow{2}{*}{$\begin{array}{l}\text { Male parent } \\
\text { (Suvarna-1) } \\
\text { Triploid }\end{array}$} & \multirow{2}{*}{$\begin{array}{l}\begin{array}{l}\text { F1 hybrid } \\
\text { (Trisomic) }\end{array} \\
\text { FEML }\end{array}$} \\
\hline & Sex type & summer & & & \\
\hline & & rainy & FEML & MLFL & FEML \\
\hline & & winter & FLBI & MLFL & FEML \\
\hline \multirow[t]{3}{*}{02} & \multirow[t]{3}{*}{ Inflorescence length $(\mathrm{cm})$} & Male & 3.09 & 4.84 & $\begin{array}{ll}--- \\
\end{array}$ \\
\hline & & Female & 3.12 & 3.28 & 3.11 \\
\hline & & Bisexual & 2.2 & 4.2 & ---- \\
\hline \multirow{3}{*}{03} & \multirow[t]{3}{*}{ Number of flowers } & Male & 20 & 50 & $\begin{array}{ll}----- \\
\end{array}$ \\
\hline & & Female & 34 & 20 & 28 \\
\hline & & Bisexual & ----- & ----- & 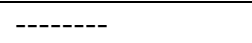 \\
\hline \multirow[t]{3}{*}{04} & \multirow[t]{3}{*}{ Peduncle length $(\mathrm{cm})$} & Male & 0.91 & 1.9 & $\begin{array}{ll}---- \\
\end{array}$ \\
\hline & & Female & 1.29 & 1.48 & 1.41 \\
\hline & & Bisexual & ----- & ----- & ----- \\
\hline 05 & \multicolumn{2}{|l|}{ Stamens length $(\mathrm{mm})$} & 2.06 & 3.03 & ---- \\
\hline 06 & \multicolumn{2}{|l|}{ Anther length $(\mathrm{mm})$} & 0.58 & 0.78 & --- \\
\hline 07 & \multicolumn{2}{|l|}{ Pollen diameter $(\mathrm{mm})$} & - & 19.43 & ----- \\
\hline 08 & \multicolumn{2}{|l|}{ Pollen viability $(\%)$} & 90 & 80 & --- \\
\hline 09 & \multicolumn{2}{|l|}{ Style length (mm) } & 0.42 & 0.77 & 0.62 \\
\hline \multirow[t]{3}{*}{10} & \multirow[t]{3}{*}{ Stigma } & Length & 3.72 & 3.77 & 3.62 \\
\hline & & Type & Erect & Erect & Erect \\
\hline & & Nature & Pubescent & Pubescent & Pubescent \\
\hline \multirow[t]{4}{*}{11} & \multirow{4}{*}{ Fruit } & length $(\mathrm{cm})$ & 2.31 & 2.83 & 2.56 \\
\hline & & width $(\mathrm{cm})$ & 1.07 & 1.09 & 1.06 \\
\hline & & Color & Black & Black & Black \\
\hline & & Taste & Sweet & Sweet & Sweet \\
\hline 12 & \multicolumn{2}{|l|}{ Seed setting (\%) } & Not determined & Not determined & 0 \\
\hline
\end{tabular}

Table-3:- Data on growth parameters of the parents and the F1 hybrid

\begin{tabular}{|l|l|l|l|l|}
\hline Sl. No. & Growth parameters & $\begin{array}{l}\text { Female parent } \\
\text { (Bird's foot) } \\
\text { Diploid }\end{array}$ & $\begin{array}{l}\text { Male parent } \\
\text { (Suvarna-1) } \\
\text { Triploid }\end{array}$ & $\begin{array}{l}\text { F1 hybrid } \\
\text { (Trisomic) }\end{array}$ \\
\hline 01 & Number of branches & 16 & 20 & 10 \\
\hline 02 & Shoot length & 164.67 & 170 & 150 \\
\hline 03 & Internodal distance(cm) & 8.12 & 7.17 & 6.68 \\
\hline 04 & Weight of 25 leaves $(\mathrm{g})$ & 48 & 80 & 71 \\
\hline 05 & Leaf area(cm2) & 98 & 228 & 238 \\
\hline 06 & Petiole weight (g) & 0.75 & 0.557 & 0.325 \\
\hline 07 & Laminar index (\%) & 80.87 & 87.49 & 86.75 \\
\hline 08 & Leaf petiole ratio by length & 6.45 & 5.5 & 3.5 \\
\hline 09 & Leaf petiole ratio by Weight & 8.01 & 9.67 & 8.32 \\
\hline 10 & Leaf shoot ratio & 1.07 & 2.04 & 1.49 \\
\hline
\end{tabular}


Table-4:- Data on propagation characters of the parents and the F1 hybrid

\begin{tabular}{|l|l|l|l|l|}
\hline SI. No. & Propagation features & $\begin{array}{l}\text { Female parent } \\
\text { (Bird's foot) } \\
\text { Diploid }\end{array}$ & $\begin{array}{l}\text { Male parent } \\
\text { (Suvarna-1) } \\
\text { Triploid }\end{array}$ & $\begin{array}{l}\text { F1 hybrid } \\
\text { (Trisomic) }\end{array}$ \\
\hline 01 & Survival (\%) & $>90$ & $>90$ & $>90$ \\
\hline 02 & Number of leaves & 23 & 35 & 32 \\
\hline 03 & Leaf length $(\mathrm{cm})$ & 18.62 & 21.61 & 18.866 \\
\hline 04 & Leaf width $(\mathrm{cm})$ & 19.06 & 15.71 & 13.101 \\
\hline 05 & Leaf weight fresh $(\mathrm{g})$ & 2.311 & 4.424 & 3.756 \\
\hline 06 & Shoot length $(\mathrm{cm})$ & 164.67 & 170 & 150 \\
\hline 07 & Shoot weight $(\mathrm{g})$ Fresh $(\mathrm{g})$ & 4 & 6 & 5 \\
\hline 08 & Number of roots & 10 & 8 & 6 \\
\hline
\end{tabular}

Table-5:- Data on Anatomical features of the parents and the F1 hybrid

\begin{tabular}{|l|l|l|l|l|}
\hline Sl. No. & Anatomical features & $\begin{array}{l}\text { Female parent } \\
\text { (Bird's foot) } \\
\text { Diploid }\end{array}$ & $\begin{array}{l}\text { Male parent } \\
\text { (Suvarna-1) } \\
\text { Triploid }\end{array}$ & $\begin{array}{l}\text { F1 hybrid } \\
\text { (Trisomic) }\end{array}$ \\
\hline 01 & Stomatal size $($ sq. $\mu \mathrm{m})$ & 221 & 355.63 & 274.97 \\
\hline 02 & Stomatal frequency $(\mathrm{sq} \mu \mathrm{m})$ & 535 & 480 & 556 \\
\hline 03 & Leaf thickness $(\mu \mathrm{m})$ & 178.1 & 183.13 & 162.11 \\
\hline
\end{tabular}

Table-6:- Data on Biochemical parameters of the parents and the F1 hybrid

\begin{tabular}{|c|c|c|c|c|c|c|}
\hline $\begin{array}{l}\text { Sl. } \\
\text { No. }\end{array}$ & Biochemical features & Type & $\begin{array}{l}\text { Female parent } \\
\text { (Bird's foot) } \\
\text { Diploid }\end{array}$ & $\begin{array}{l}\text { Male parent } \\
\text { (Suvarna-1) } \\
\text { Triploid } \\
\end{array}$ & $\begin{array}{l}\text { F1 hybrid } \\
\text { (Trisomic) }\end{array}$ & $\begin{array}{l}\text { Signific- } \\
\text { ance }\end{array}$ \\
\hline \multirow[t]{3}{*}{01} & \multirow[t]{3}{*}{ Protein content $(\mathrm{mg} / \mathrm{g})$} & Tender & $14.78 \pm 0.34$ & $14.93 \pm 1.20$ & $13.42 \pm 0.56$ & Ns \\
\hline & & Medium & $14.32 \pm 1.20$ & $13.40 \pm 0.43$ & $14.60 \pm 0.22$ & Ns \\
\hline & & Coarse & $11.20 \pm 1.157$ & $11.23 \pm 0.45$ & $11.78 \pm 0.07$ & Ns \\
\hline \multirow[t]{3}{*}{02} & \multirow{3}{*}{$\begin{array}{l}\text { Carbohydrate content } \\
(\mathrm{mg} / \mathrm{g})\end{array}$} & Tender & $7.03 \pm 0.55$ & $6.75 \pm 0.30$ & $6.91 \pm 0.16$ & $* *$ \\
\hline & & Medium & $13.54 \pm 0.38$ & $12.11 \pm 0.38$ & $13.62 \pm 0.14$ & $* *$ \\
\hline & & Coarse & $11.46 \pm 0.34$ & $12.65 \pm 0.27$ & $11.13 \pm 0.25$ & Ns \\
\hline \multirow[t]{3}{*}{03} & \multirow{3}{*}{$\begin{array}{l}\text { Chlorophyll a content } \\
(\mathrm{mg} / \mathrm{g})\end{array}$} & Tender & $1.74 \pm 0.09$ & $1.71 \pm 0.04$ & $1.74 \pm 0.16$ & Ns \\
\hline & & Medium & $2.54 \pm 0.11$ & $2.64 \pm 0.01$ & $2.49 \pm 0.07$ & $*$ \\
\hline & & Coarse & $2.26 \pm 0.03$ & $2.30 \pm 0.005$ & $2.22 \pm 0.07$ & Ns \\
\hline \multirow[t]{3}{*}{04} & \multirow{3}{*}{$\begin{array}{l}\text { Chlorophyll b content } \\
(\mathrm{mg} / \mathrm{g})\end{array}$} & Tender & $0.70 \pm 0.51$ & $0.68 \pm 0.03$ & $0.59 \pm 0.04$ & $* *$ \\
\hline & & Medium & $0.90 \pm 0.10$ & $0.73 \pm 0.03$ & $0.77 \pm 0.05$ & $*$ \\
\hline & & Coarse & $0.84 \pm 0.01$ & $0.66 \pm 0.03$ & $0.68 \pm 0.11$ & $*$ \\
\hline \multirow[t]{3}{*}{05} & \multirow{3}{*}{$\begin{array}{l}\text { Total chlorophyll } \\
\text { content }(\mathrm{mg} / \mathrm{g})\end{array}$} & Tender & $2.54 \pm 0.11$ & $2.64 \pm 0.01$ & $2.49 \pm 0.07$ & $*$ \\
\hline & & Medium & $3.45 \pm 0.07$ & $3.38 \pm 0.04$ & $3.26 \pm 0.05$ & $* *$ \\
\hline & & Coarse & $3.10 \pm 0.37$ & $2.97 \pm 0.04$ & $2.91 \pm 0.19$ & Ns \\
\hline 06 & Moisture contents (\%) & -- & 69.86 & 60.67 & 72.43 & -- \\
\hline 07 & $\begin{array}{l}\text { Moisture contents after } \\
6 \text { hours }\end{array}$ & -- & 66.94 & 51.98 & 69.37 & -- \\
\hline 08 & $\begin{array}{ll}\text { Moisture } & \text { retention } \\
\text { capacity }(\%) & \end{array}$ & -- & 73.76 & 58.09 & 76.87 & -- \\
\hline
\end{tabular}




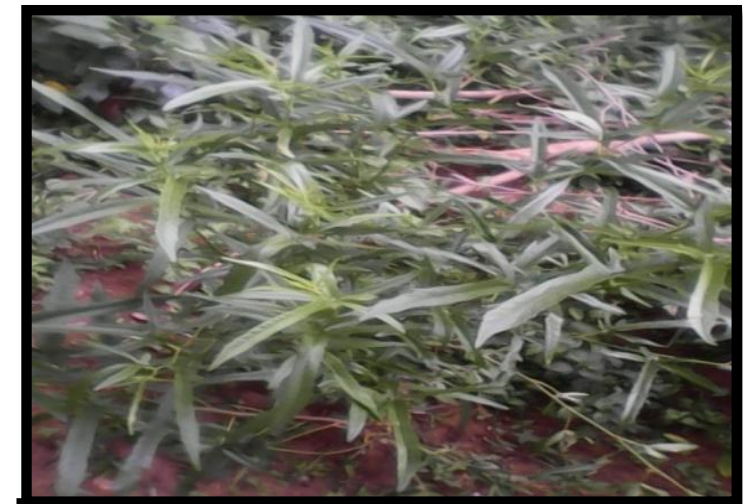

Fig. 1: A bush of mulberry genotype Bird's foot (Female parent)

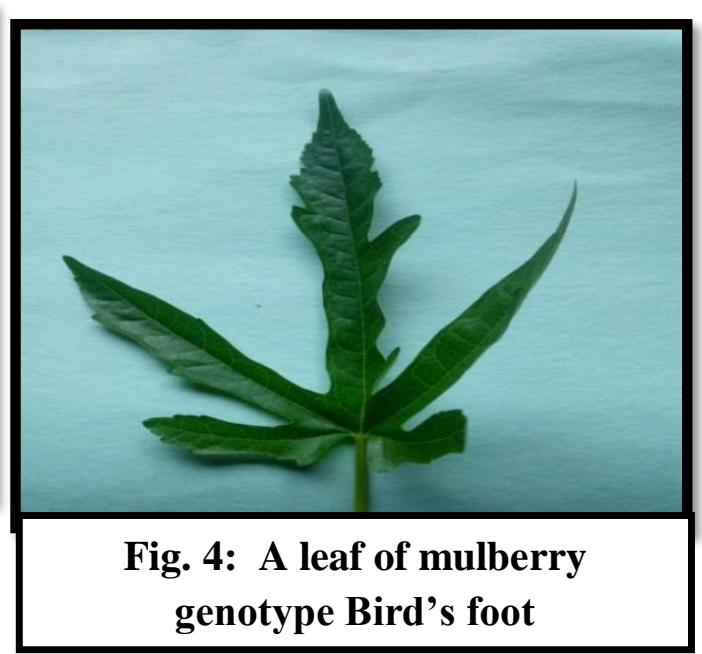

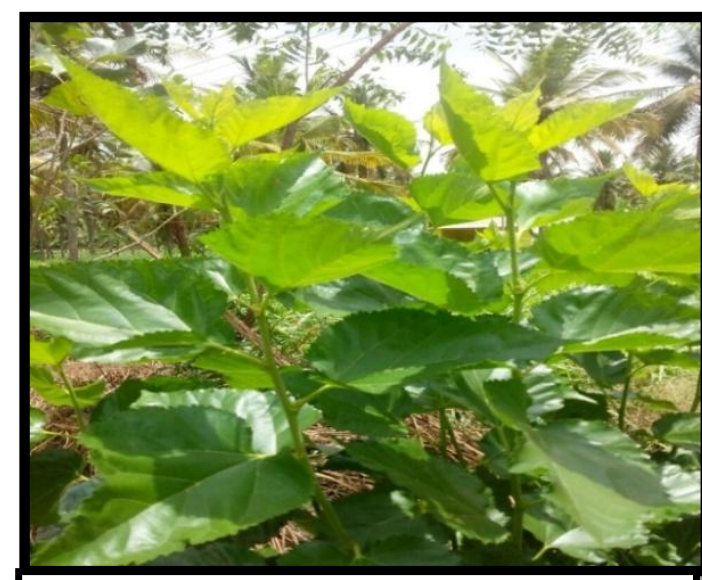

Fig. 2: A bush of mulberry genotype Suvarna-1 (Male parent)

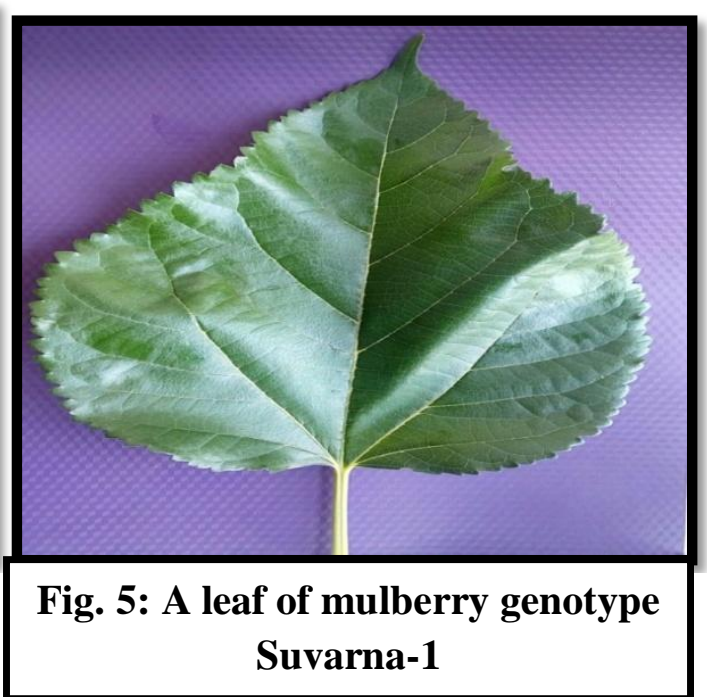

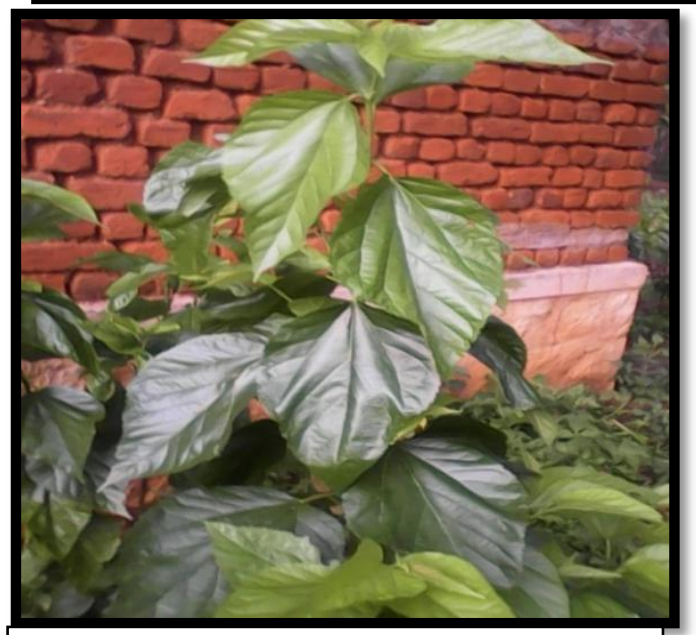

Fig. 3: Selected F-1 hybrid of bird'foot $X$ suvarna-1

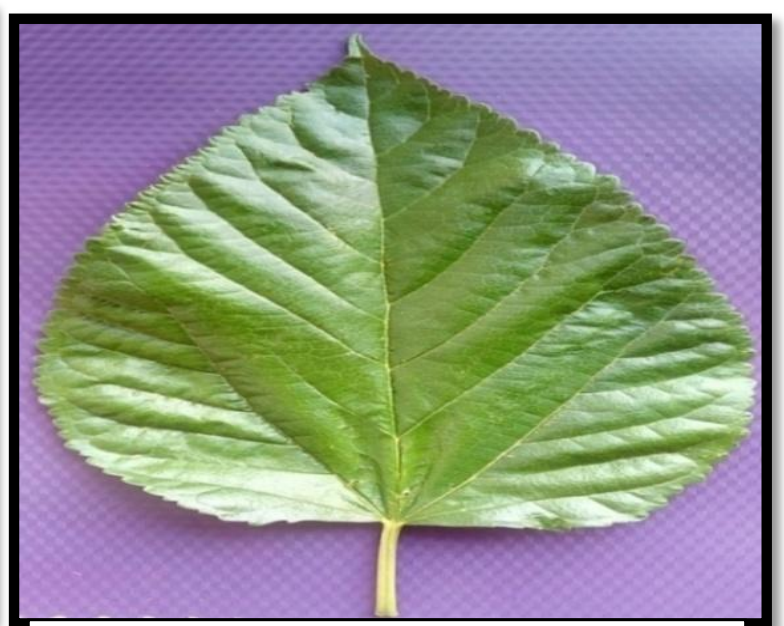

Fig.6: A leaf of mulberry F-1 hybrid 

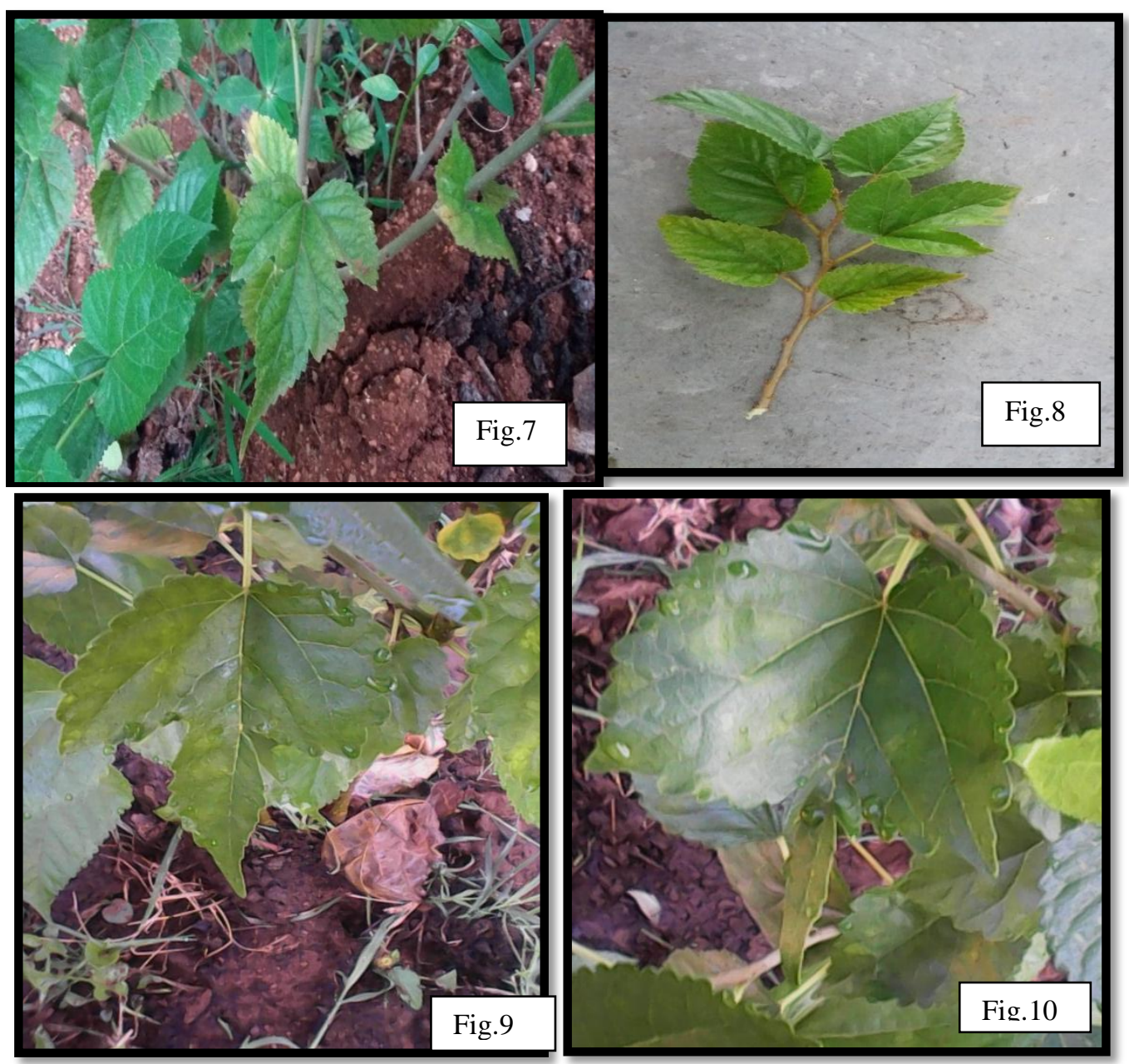

Figures 7to 10:- Various types of leaf lobation in F-1 hybrid progenies of cross between Bird's foot and Suvarna-1

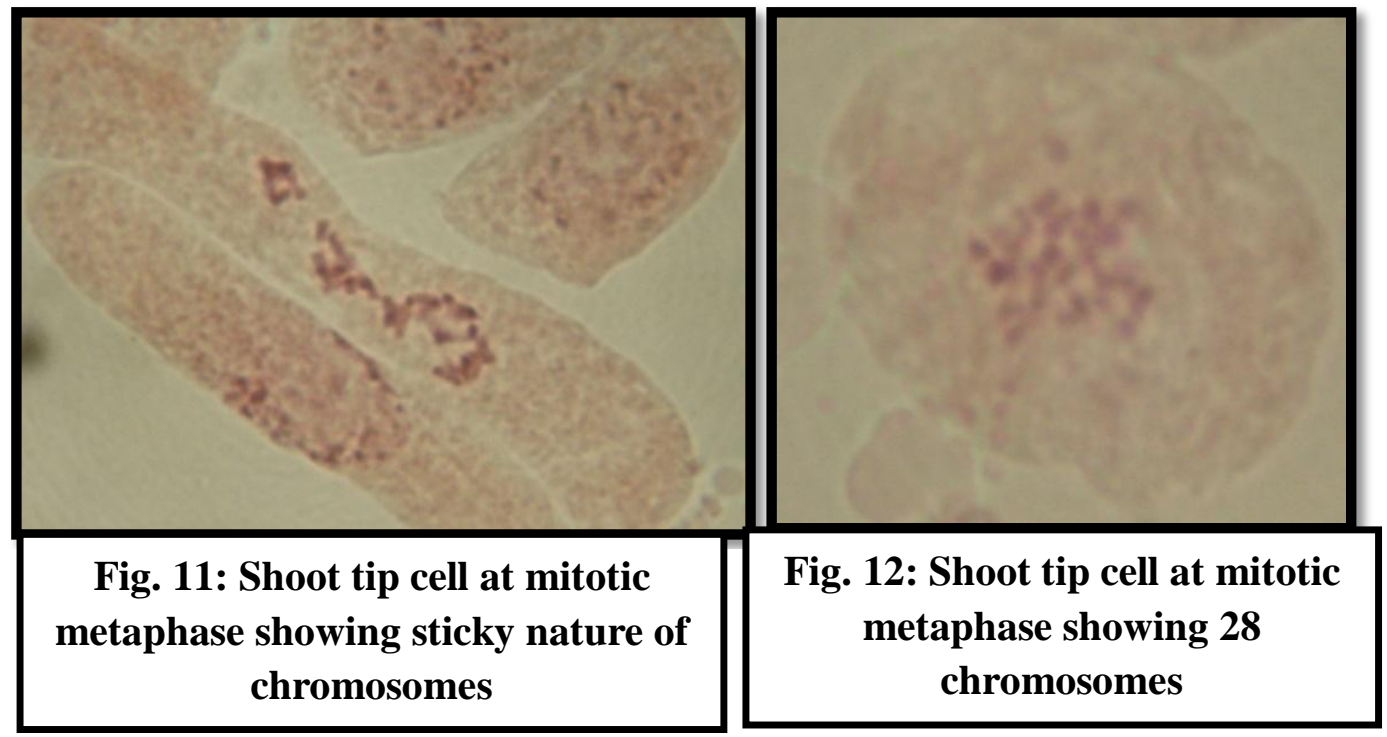



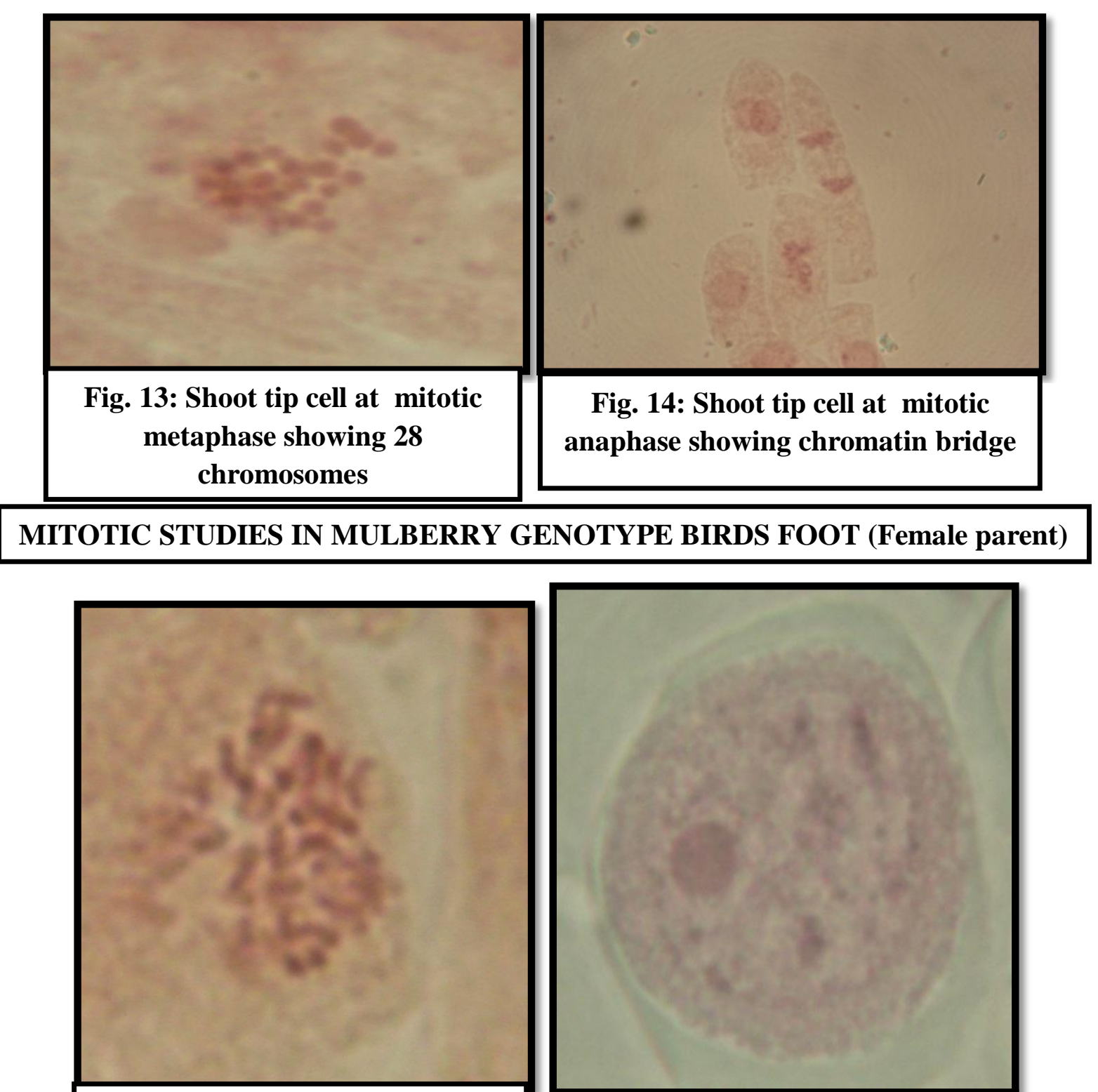

Fig. 15: Shoot tip cellat mitotic metaphase showing 42 chromosomes

Fig. 16: PMC at leptotene 


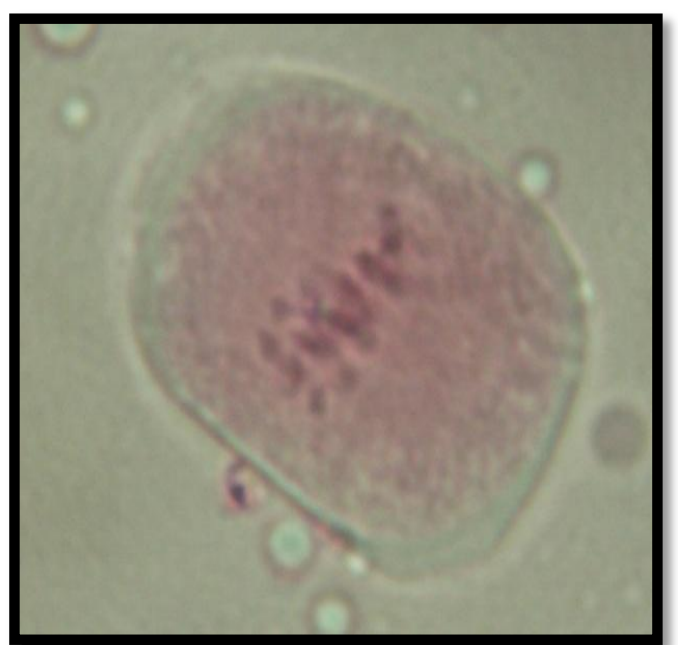

Fig. 17: PMC at metaphase -I

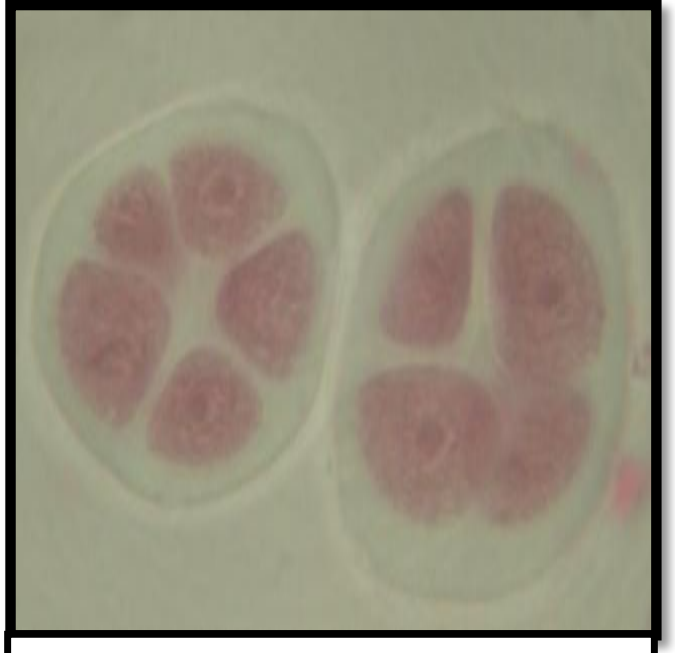

Fig. 19: A pentad and a tetrad

MEIOTIC STUDIES IN MULBERRY GENOTYPE SUVARNA-1 (Male parent)

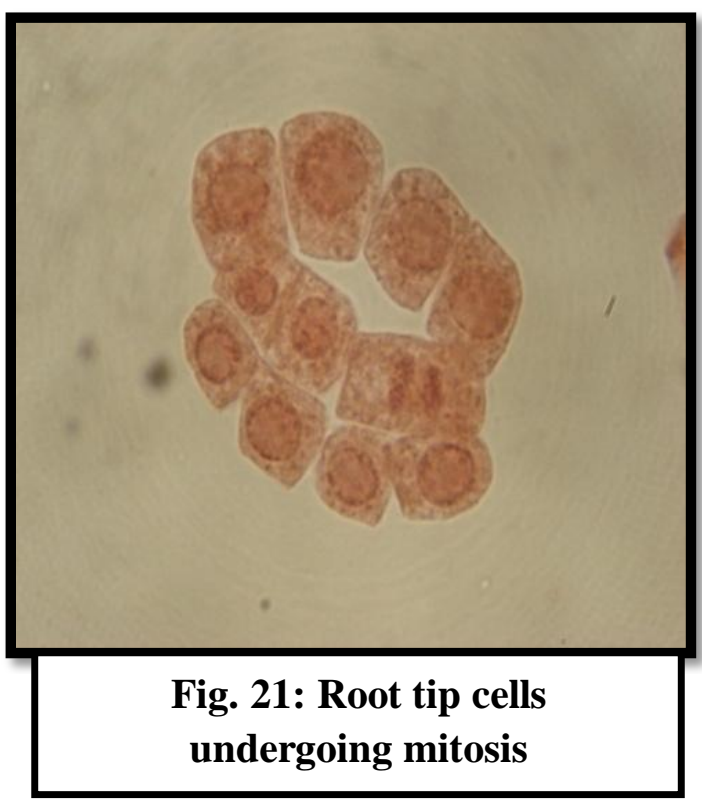

Fig. 18: PMC at anaphase- I
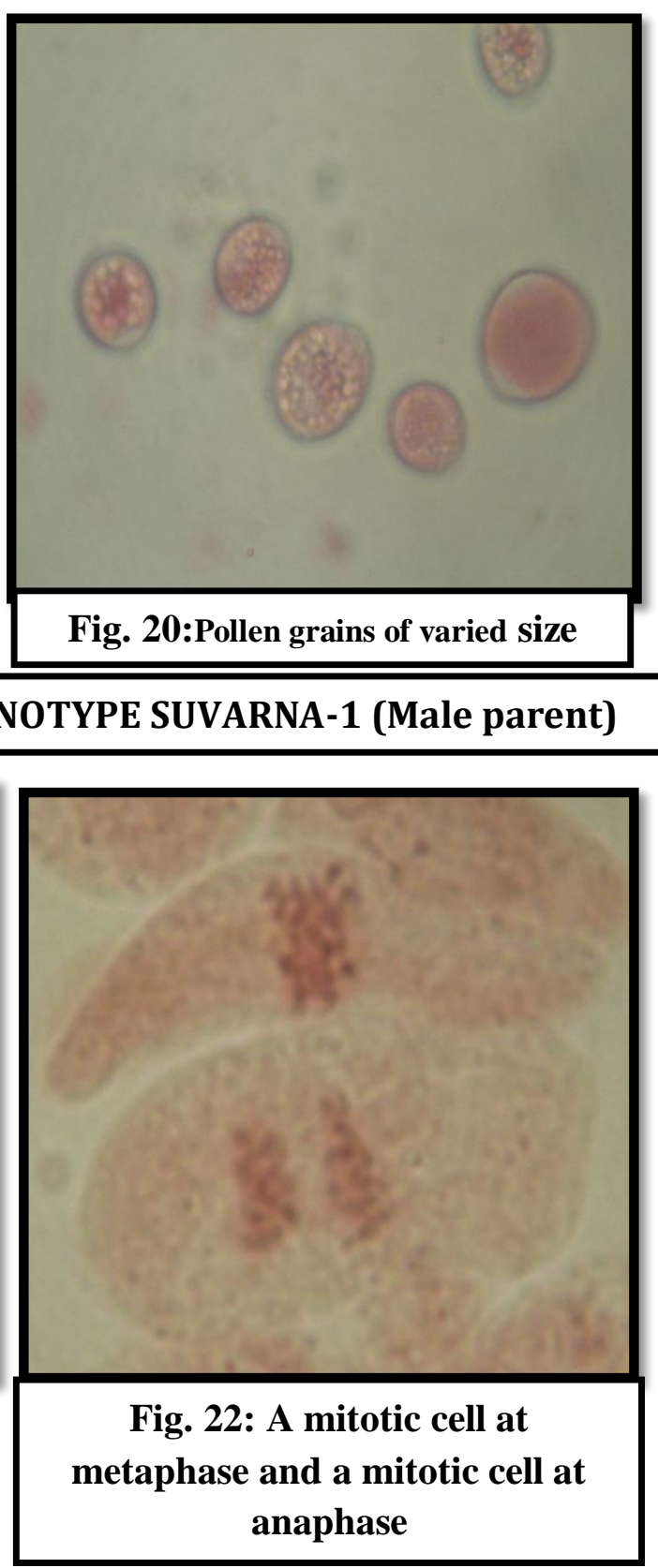


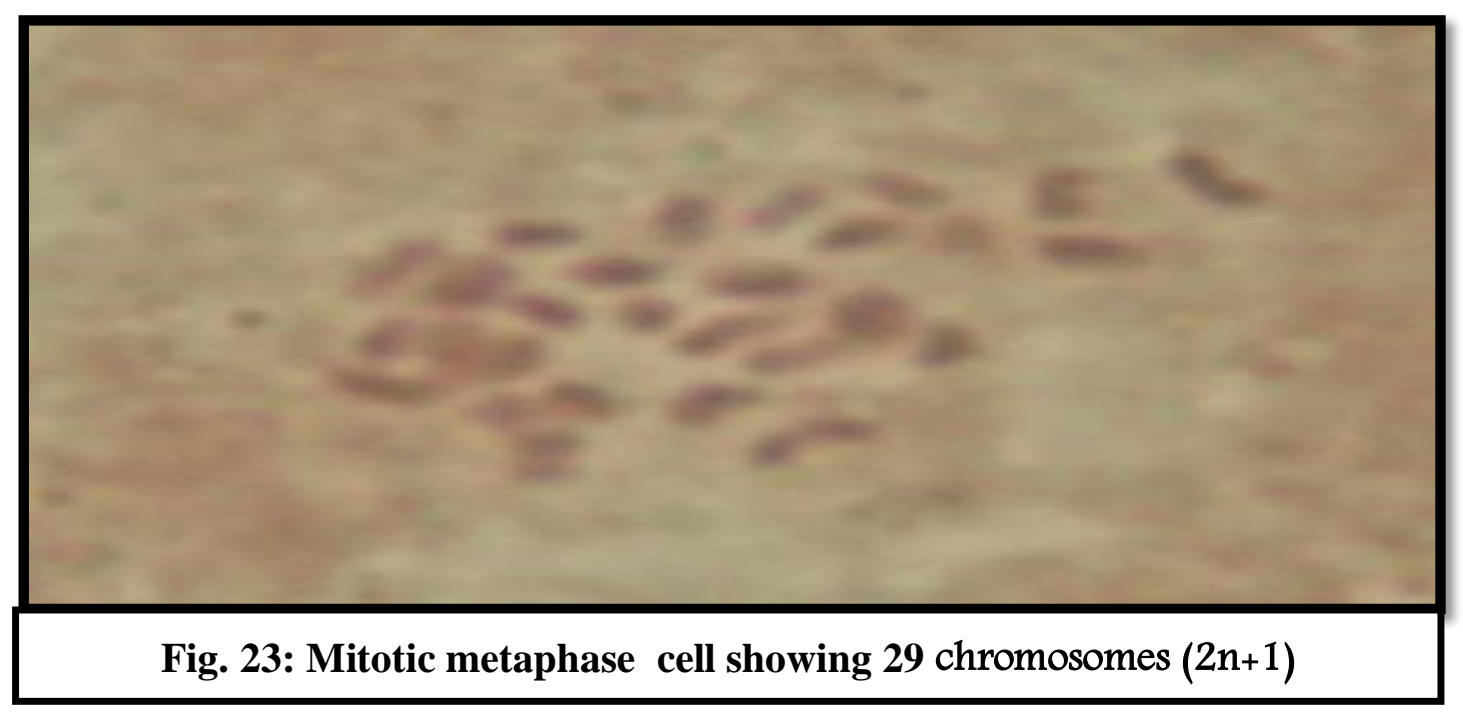

\section{References:-}

1. Esen, A.andSoost, R.K.1972. Aneuploidy in Citrus. Amer. J. Bot., 59(5): 473-477.

2. Basavaiahet.al., 1990.Chromosomal association and meiotic behavior of triploid varieties of mulberry (Morus spp.).Cytologia, 55:325-333.

3. Chakraborti, S.P.,Vijayan, K. and Boss, S.G.1999.Varietal difference of karyomorphological of some popular cultivars in mulberry (Morus spp.).Sericologia,39:43-50.

4. Dandinet.al.,1987. Crossability studies in mulberry. India J. Seric.,26: 1-4.

5. Dandin, S.B., Jayaswal and Giridhar,K.(Eds.) 2003. Handbook of Sericulture Technologies.CSB, Banglore.

6. Daset.al., 1970. Studies on anthesis in mulberry. Indian J. Seric.,9:59-63.

7.

8. Datta, M. 1954. Cytogenetical studies on two species of Morus. Cytologia, 19: 86-94.

9. Kundu, D. and Sharma, A. 1976.Chromosome studies in some Indian Moraceae. Recent advance in Botany.pp.348-365.

10. Dzhafrov,N.A. and Nadzhafrov.F.N. 1984. Production and study of interspecific mulberry hybrids of different ploidy. Plant breeding abstract,54: 160.

11. Gray, E. and Gray, E.R. 1987. Leaf lobation patterns in mulberry. Castanea, 52: 216-224.

12. Gill, B.S. and Gupta,1970.Cytological studies in six types of Morus alba. Curr. Sci., 48:35-36.

13. Gill, B.S. and Gupta, R.C. 1979. Cytological studies in the sex types of MorusalbaL. Moraceae. Curr. Sci., 48(1): 35-36.

14. Giura,1989. Off-Type Plants in wheat by aneuploidy. National Agricultural Research and Development Institute,Fundulea. pp. 5-9.

15. Hussain, S.W. and Willians, 1997. Evidence of functional unreduced gametes in Trifoliumrepens L.

16. Janaki Ammal, E.K. 1948, The Origin Of Black Mulberry.J.Roy.Horti.Sci.,73: 117-120.

17. Jyothiet al.2014. Studies on biochemical constituents of different genotypes of Morusalba L. International Journal of Pharma and Bio Sciences, 5:835-840.

18. Katsumata F, 1982, Inheritance of some of the traits in an interspecific hybrid between Moruskagayamaekoidz. And kairyonezumigaeshi (a farm Morusalba L.), 381-388.

19. Khush G.S, 1973. Cytogenetics of aneuploids. Academic press Inc., New York.

20. Kichisaburominamizawa. Moriculture text book.

21. Laltanmawii and Roychowdhuri, S. 2010 Effects of chromosomal variations on morphology and leaf anatomical behaviours in mulberry (Morus spp.). J.CropandWeed. 6(2): 35-39.

22. Mukherjee,S.K. 1965. Breeding of mulberry in India by use of a pollinator - the pollen gun. Sci.Cult.,31:101104.

23. Sarkar, A. 2010. Mulberry Breeding. Kalyani publishers, New Delhi.

24. Peris, W.N.et al. 2014. Morphological characterization of mulberry (Morus Spp.) Accessions Grown In Kenya. Sustainable Agriculture Research.,3(1): 10-15. 
25. Osawa, I. 1920. Cytological and experimental studies in Moruswith special reference to triploid mutants. Bull. Imp. Seric. Expt. Stn.,1(1): 318-366.

26. Osuji.et al. 1997. Ploidy variation in hybrids from interploidy3x X2x crosses in Musa.Fruits.47:641-351.

27. Singh, B.D.2000. Plant Breeding-Principals and Methods.Kalyani publishers, New Delhi.

28. Shimelis, H. And Spies, J.J. 2011. Aneuploids of wheat and chromosomal localization of genes. African J.Biotech.10(29):5545-5551.

29. Sikdar, A.K. and Jolly, M.S. 1994. Anatomical and cytological studies of diploid and polyploids of mulberry. Proc. Conf.Cytologia and Genetics, 4:87-95.

30. Singahal, B.K. et al.1999. SEM studies on the leaf surface of promising mulberry (morusspp.) genotypes. Journal of Plant Biology. 42:71-74.

31. Singhalet al.,2010. Leaf surface scanning electron microscopy of 16 mulberry genotypes (Morus Spp.)with respect to their feeding value in silkworm (Bombyx Mori L.) Rearing. Chilean J., 70: 191-198.

32. Park, M.S.,et al., 2012. Frequencies of aneuploids seedlings obtained apple accessions (malus x domestica ) pollinated with diploid 'hongro'J.fac.agr.,57(1):67-72.

33. Suryanarayan, 1990. Cytogenetical studies on two species of Morus. Cytologia,55: 327-333.

34. Susheelamma, B.N., Jalaja, S.K., Dandin, S.B., Jolly, M.S., Sengupta, K. and Raju, R. 1990. Karyomorphological studies in a few exotic varieties of genus Morus L. Cytologia, 55(1): 107-114.

35. Susheelamma, B.N., Jalaja, S.K., Dandin, S.B., Jolly, M.S., Sengupta, K. and Raju, R. 1990. Karyomorphological studies in a few exotic varieties of genus Morus L. Cytologia, 55(1): 107-114.

36. Tangaveluet al. 1997. Catalogue on mulberry (morus spp.) germplasm-volume I, central sericulture germplasm resources center, central silk bord, Mysore.

37. Tikader, et al., 1999. Pollen morphology studies in mulberry (Morus spp.) Indian J. Seric.,39:160-162.

38. Venkateshet al. 2014. Morphological, Anatomical And Reproductive parameters in few varieties of mulberry (morus spp.). International Journal Of Advanced Biological Research.Vol,4(1):73-75.

39. Venkatesh, K.H. 2007. Cytological investigation in genus Morus L. Ph.D.Thesis. Bangalore University, Bangalore.s

40. Venkatesh, K.H. and Munirajappa. 2013. Cytogenetical studies in two tetraploid mulberry varieties (Moraceae). Int. Soc. Chromosome Bot.8: 65-69.

41. Venkatesh, K.H., Shivaswamy. S., Dinesh. B. and Munirajappa. 2014. Meiotic studies in two diploid varieties (Morus spp.). Indian J. Appl. Res. 4(9): 69-70.

42. Venkatesh, K.H., Shivaswamy. S., Dinesh. B. and Munirajappa. 2014. Meiotic studies in two diploid varieties (Morus spp.). Indian J. Appl. Res. 4(9): 69-70.

43. Venkatesh.K,H. Munirajappa and Shivaswamy,S.2014 studies on cytomorphology of two mulberry varieties (moraceae).Indian journals of applied research. Vol(4)486-488.

44. Venkateshwarulu. M, Susheelamma. B. N, Suryanarayana. N, Dwivedi. N. K, Sengupta. K., 1989, Peroxidase isoenzyme banding petterns in aneuploids of mulberry. J. Sericologia. 29:99-104.

45. Vijayan, et al.,cytomorphologicalcharecteristics of colchicines induced chimeri mutant in mulberry, cytologia 63: 27-31.

46. Vijayan, K., Tikader, A., Kar, P.K., Srivastava, P.P., Awasthi, A.K., Thangavelu, K., Saratchandra, B. 2006. Assessment of genetic relationships between wild and cultivated mulberry (Morus) species using PCR based markers. Genetic Resources and Crop Evolution, 53: 873-882.

47. Vineet Kumar et al. 2012. Leaf and Anatomical Traits In Relation To Physiological Characteristics In Mulberry (MORUS spp.). Turk J Bot. 36 : 683-689. 